\title{
MERGER AND INDUSTRIAL ACCELERATION: STUDY AT INDONESIAN ISLAMIC BANKING INDUSTRY
}

\author{
Kindy Miftah', Hendro Wibowo \\ 'Maybank Indonesia, ${ }^{2}$ STIE SEBI \\ 'kindy.miftah@ymail.com, ${ }^{2}$ hendro.wibowo83@gmail.com
}

\begin{abstract}
The purpose of this research tries to feed the alternatives of merger between Islamic banks, which becomes a form of recommendation to optimize the merger result, so it will contribute to the development of Indonesia's banking sector in particular. Methodolgy of this study is using comparison technique utilize result of calculation valuation based on valuation theory in general with method discounted cash flaw (DCF). Valuation data processing using data past performance sharia banks is to plan future financial performance. Results of valuation will be conducted both with individual banks that will be merged and alternative merger determined. These findings implied from various possibility alternative mergers between sharia banks, there are 5 alternatives that are feasible considering the internal aspect such as tendency shareholder and condition sharia bank to be merged related to internal interest and external aspect namely scale of assets from merger banks and probability success from merger process.
\end{abstract}

Keywords: Islamic banking, merger, valuation, discounted cash flow.

\begin{abstract}
Abstrak
Tujuan dari penelitian ini adalah memberikan gambaran terkait alternatif-alternatif merger antar bank-bank syariah yang dapat diambil serta memberikan rekomendasi alternatif merger yang paling optimal untuk kondisi saat ini, sehingga memberikan kontribusi terhadap pengembangan sektor perbankan dan sektor keuangan di Indonesia. Metodologi penelitian ini ialah menggunakan teknik perbandingan memanfaatkan hasil perhitungan valuasi berdasar teori valuasi secara umum dengan metode discounted cash flow (DCF). Pengolahan data valuasi menggunakan data kinerja bank-bank umum syariah untuk memproyeksikan kinerja keuangan di masa mendatang. Hasil valuasi dilakukan baik atas individu masing-masing bank yang akan dimerger maupun atas alternatif merger yang ditentukan. Hasil penelitian menunjukkan alternatif merger antar bank syariah hanya terdapat 5 alternatif yang feasibel mempertimbangkan aspek internal berupa tendensi pemegang saham dan kondisi bank syariah yang akan dimerger terkait kepentingan internalnya, serta aspek eksternal yaitu besaran aset dari bank hasil merger dan probabilitas sukses dari proses merger.
\end{abstract}

Kata kunci: perbankan syariah, merger, valuasi, discounted cash flow.

Received: January 3, 2017; Revised: January 30, 2017; Approved: February 28, 2017 
Merger and Industrial Acceleration...

Kindy Miftah, Hendro Wibowo

\section{INTRODUCTION}

The sharia banking market share which is stagnant below $5 \%$ and the growth tends to be stagnant made Islamic banking industry at a crossroad. With small asset both industrial and Islamic banking individual, the majority stakeholder of sharia banking express needs to find new innovation to encourage back the growth of industry including the anorganic way. The issue of conversion or merger has been warm issues over the last 3 years. Formulation that is necessary to converse or merger becomes a very relevant issue in the condition of sharia banks that lacks of efficiencies and unable to compete with huge banks in national even regional level. Several of alternatives had been raised many parties including conversion of Bank BTN into sharia bank and the merger of sharia banks subsidiary government banks. Conversion bank BTN become sharia bank which will significantly increase the industrial asset and market share of sharia bank by considering BTN asset has reached IDR I7I.8 trillion (20I5), this lack of realistic alternative is caused by the strategic role of BTN in supporting public housing program and some other options related to the optimization of Bank BTN as government bank.

Planning for developing an organic then lead to merger option, especially with object sharia banks subsidiary government bank (BUMN banks) consists of 4 banks: Bank Sharia Mandiri, BNI Sharia, BRI Sharia and BTN Sharia. Discourse merger will be directed through merger. Therefore those 4 sharia banks should merge into I (one) sharia general banks that assets and capital are formed can become larger, that is expected to compete with high conventional bank and sharia banks in regional level.

As a part of support, some parties especially sharia bank practice, mostly explains disagreement with the idea of mergering sharia bank and unit of government bank with the reason that it's not a solution towards market share sharia bank and also the position is still beyond top ten. However, contra parties are also not denying the related to impact of scale efficiency generated after the post merger.

If analyzed in a simple way, the merger will not enhance market share of the sharia bank; in contrast it is to the impact if conversion is conducted. If BTN bank is converted, then assets and market share of the sharia bank industry will attain IDR 500 trillion or $7.5 \%$, but if option merger will be done then the result will be the same as the condition before the merger. 
Problems in sharia bank performance for the last 3 years actually have illustrated that scale of sharia bank business has not been able to manage business quality on higher assets. Stagnation assets infected by condition two top sharia banks that have assets above IDR 50 trillion shows that the capacity of sharia banks is untested by top managing on a large portfolio, which is particularly related to business productivity and risk management.

One important issue in this act is the obligation for Islamic business unit (UUS) to do the spin-off if they had reached the $50 \%$ of the parent's asset or 15 years after the establishment of this act. After the establishment of this act, there are several Islamic business units that had done the spin-off, either by creating new companies or by using the existing companies. If we are referring to the spin-off's criteria in the act, there is no Islamic business unit that had been reached the $50 \%$ parent's asset. Al Arif (20I5a) said that the spin-off doesn't give an impact on asset growth. Besides that Al Arif $(2015 b)$ found that spin-off decrease the operational efficiency of Islamic banking industry. According to Ismawati (2017) the forecasting by using ARIMA shown that there is no sharia unit owned by Regional Development Bank can achieve the $50 \%$ of the parent bank asset. From these results, implies that the spin-off criteria should evaluate because there are no sharia unit can be achieved the 50\% share asset in 2023 . Although Hamid (2015) found that spin-off had an impact on profitability in Islamic banking industry.

Figure I. The Development of NPF and Profit Sharia Banking
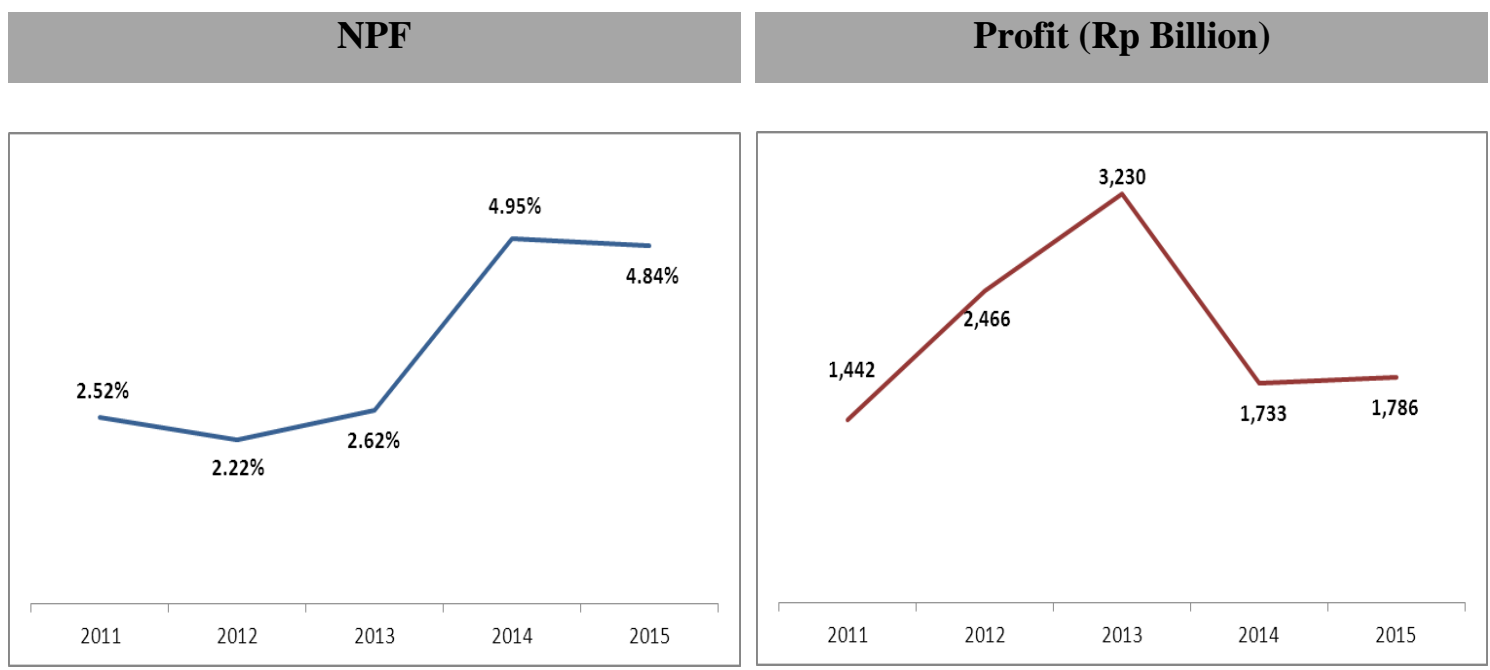

Source: Sharia Banking Statistics 20I5, OJK 
Merger and Industrial Acceleration...

Kindy Miftah, Hendro Wibowo

Although it has been many years in managing financial segment corporate/commercial, sharia banks are still proven vulnerable when financial is in trouble. Strength in small medium enterprise and consumer that has been built is not enough to be able to restrain impact from decreasing quality finance segment corporate/commercial. Indicator ratio non-performing financing (NPF) in bank widely has a direct loss which it impacts significantly to profit or in its overall ability to expand in finance. It certainly can be minimized if assets of the sharia bank are larger, so the scale to absorb financiall impact is also greater.

NPF sharia banking in December 2015 as $4,84 \%$ or only falls slightly from the position of December 2014 as 4,95\%. Meanwhile, the deviation also has increased and depressed profit. The deviation for financing in 2015 is as IDR 10,2 trillion, so profit can only reached IDR I,7 trillion, or profitability only produce return of equity (ROE) of $8,5 \%$.

In the last 2 years, a large sharia banks has tended to hold growth of financing because of the focus on improving quality portfolio financing. BSM financing growth is as $7 \%$ and Muamalat bank as $-1,2 \%$ on average in 2014 and 2015 . As a result, the growth of sharia bank industry financing only grew 7-8 \%. Lowering in financing growth also would potentially weaken the position market share sharia bank nationally in medium or long term.

\section{Figure 2. The Development of Sharia Banking Financing Growth}

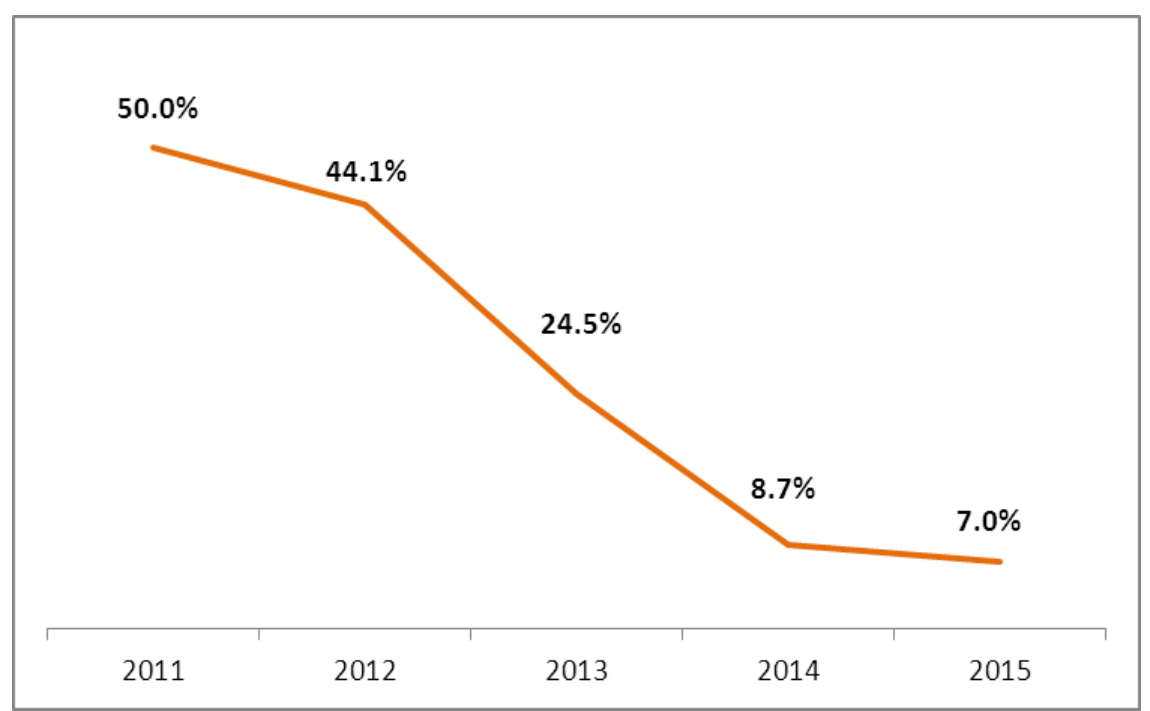

Source: Sharia Banking Statistic 2015, OJK 
In terms of merger action, national bank industry actually had experience both small and large merger. Merger 4 (four) banks state-owned/government banks to address crisis 1998 become a history merger because the level of complexity and situation exists in the merger process. Merger Bank Dagang Negara (BDN), Bank Bumi Daya (BBD), Bank Pembangunan Indonesia (Bapindo) dan Bank Ekspor Impor (Bank Exim) transformed into Bank Mandiri, it had a high level of complexity because each bank has its own problems with different business segment. Chasing time with handling economic crisis and multidimensia that have high potential for failure also did merger.

Besides the merger case of Mandiri Bank, other large merger actions were a process merger of Niaga Bank and Lippo Bank into CIMB Niaga Bank. Merger process is motivated by bank ownership regulation and intention from Lippo Group to release ownership from the Lippo Bank. As a large bank with relatives in the same large, difficulty of this merger were to integrate products, system and policies because conversion process to anchor bank was relatively difficult. With the customer as well as many, they attempted to get approval and answers from the customers who were related to impact of merger, which was not simple.

As a result, Mandiri Bank has currently become the largest national bank with assets increased $325 \%$ compared to previous assets when merger. CIMB Niaga Bank has also become a leading player in banking industry and become an excellent bank especially in regional transactions supported by CIMB Group. Assets of CIMB Niaga Bank have increased by $226 \%$ compared to combine assets of Niaga Bank and Lippo Bank when the merger carried out.

The experience of Bank Mandiri and Bank CIMB Niaga also proved that a successful merger not only affects internally in bank business or shareholder but also brings a very positive impact towards the development and financial system stability. The same is expected in sharia bank industry, so when a s haria bank industry grows healthier and more stable after merger policy then when market share enlarge, the impact would be very positive for the stability bank system and national finance. 
Merger and Industrial Acceleration...

Kindy Miftah, Hendro Wibowo

\section{METHOD}

Methods on this study is using comparison technique utilize result of calculation valuation based on valuation theory in general with method discounted cash flaw (DCF). Valuation data processing using data past performance sharia banks is to plan future financial performance. Results of valuation will be conducted both with individual banks that will be merged and alternative merger determined. Data that are used in valuation have been historical data from each bank that become an object merger during 4 years before 2016 then is made into financial projections next 5 years.

Besides comparing valuation result, this study will also analyse the synergy of merger that is created specially in term of business models. Compatibility and value added in this business model resulting from merger will be a consideration point related to the alternative merger that is considered optimal as a study conclusion. Before entering into valuation stage, the study will use qualitative data on sharia commercial bank that has the largest assets ( 12 bank) to formulate alternatives merger. The reason based on assets is to get optimal result merger in influencing market share of the sharia bank.

Table I. List of Banks that is the Object of Study

\begin{tabular}{ll}
\hline Sharia Commercial Bank & Sharia Business Unit \\
\hline - Bank Sharia Mandiri & - Permata Bank Sharia \\
- Bank Muamalat Indonesia & - BTN Sharia \\
- Bank BNI Sharia & - Bank CIMB Niaga Sharia \\
- Bank BRI Sharia & - Bank Danamon Sharia \\
- Panin Bank Sharia & - Bank Maybank Indonesia Sharia \\
\hline
\end{tabular}

Company valuation is a procedure/method to get valuation from a company or share. Pratt (2008) explains that practical approach is often used to do valuation and grouped into 3 approaches: First, income approach that valuation based on cash flow as a form of corporate profit. Second, market approach that valuation based on price and indicators that are formed on the market. Third, Asset based/balance sheet approach that valuation based on development of company assets value. 
In financial philosophy, the value of a company is an amount of future benefit return, which is produced by company. The revenue is then discounted by an appropriate discount so that present is obtained from the value of total revenues. This approach focuses on effort to quantification ability of a company to generate return to the owner. From these approaches, this research will use income approach considering that this approach is best practiced used by the capital market user in order to valuate bank currently.

By using this approach, value of company can be obtained by discounting future cash flow that is generated from these statements (discounted future return, DFR). With these methods, there will be three important things to do: (I) define net cash flow (DCF) or profit in accordance with the nature and type of business, (2) project cash flow in particular period, (3) sets level of discount (discount rate) reasonably and properly so present value can be aquired from that company.

This approach assumes that a business will continue (on going concern business). In this approach, there will be 2 methods that can be used to set a value indication of a business, that is: (I) Method of Income Capitalization. Method that is based on one of profit figures that are considered as represent ability in the future from a company or business interest. It is assessed and divided with a level of capitalization or multiplied with capitalization factor that become an indication from the interest of a company or business. (2) Analysis of discounted cash flow. A financial model technique is based on assumption prospect cash flow of a property or business. As an acceptable method in profit approach, analysis DCF involves projection cash flow for a period, both to assess assets, business and property. Projection cash flow requires discount for present market today to get an indication current value of cash flow related to asset, business or property.

This method is based on calculation of future profit (future return) from running company. Future return is from free cash flow after increased or decreased with increase or reduction obligation. Free cash flow is based on net income plus non-cash expense (non cash charge), then reduced investment in working capital and fixed assets (capital expenditure). Results of free cash flow then discounted with level of discount so present value of free cash flow can be obtained. 


\section{RESULT AND DISCUSSION}

Merger and Acquisition are part of restructuring company strategic which have the same primary goal with the ultimate goal company that provides value added for investor or shareholder. Philosophically, decision to merger and the acquisition are influenced by belief that to synergy between companies will be better than running company with the same business separately. Practice and researches related to merger and acquisition have proved that there are alot of added values that can be obtained from decision to merger or acquisition.

Gitman and Zutter (20I2) classify-merger in broad meaning into 3 types: First, horizontal merger is a merger between two companies with the same activities business with the goal to expand the company operationally and to achieve better economic scale. Second, vertical merger is a merger where buyer is to acquire supplier in making one business entity. The purpose of this merger is to improve production cost so buyer will no longer pay a huge margin to supplier. Third, conglomerate merger is a merger between companies who have different sectors or business chain. This purpose merger is to diversify the business from the owner and to make process control more efficient.

In practice, almost all merger transactions involve two companies. Transaction merger generally was initiated by a company that earlier acquires another company in the same sector and than to be merged with company that has been previously owned. It is very rare that a merger is initiated equally by two owners which one of them doesn't sell or reduce his ownership.

Although it looks like many companies are becoming more successful after running merger, many cases of merger also fail. Some success factors and failure in merger are in Table 2:

In company case merger, the conceptual valuation is also considered a value of synergy formed by companies that have merged. Impact of synergy as financial is to increase potential resource to get more benefit and also efficiency. Calculation valuation on merger companies will consider potential of this synergy as well as only considering the project individually but presented on consolidated base (stand alone base). Valuation calculation in stand alone model generally only can be used as a value 
base to calculate valuation on synergy model, meaning that valuation on synergy model must be bigger than stand alone model.

Table 2. The Success and Failure Factors in the merger process

\begin{tabular}{ll}
\hline \multicolumn{1}{c}{ Success Factors } & \multicolumn{1}{c}{ Failure Factors } \\
\hline - Match in strategic vision & - Lack of vision and leadership \\
- Due Diligence goes well & - Loss of momentum business during \\
- Pre-merger planning and Post- & - Ferger and consolidation process \\
merger Integration & merger transaction \\
- External factors like economic & - Organization chaos \\
conditions and business climate & - Human Resource and culture \\
& conflict \\
\hline
\end{tabular}

Source: Epstein (2005) and Weil \& Cole (2008)

Johnson, et.al (1994); Hite et.al (1984) stated that one of the factors that determine the success of spin-off is the size of the parent company. The larger the company, the better success of spin-off would be than the smaller company. LindholmDahlstrand (2000) showed that the firm's size becomes one of the factors that influence the growth of the subsidiary as the result of the spin-off. If this matter associated with the process of Islamic business unit spin-off in Indonesia, then it would be a problem for Islamic business unit spin-off process owned by Banks where most of the Banks have a small size. Hamid (2015) the empirical result obtained on this study indicate that the spin-off policy that pursued by the central bank is right. Although there are still some policies are still needed by the Islamic banking industry to grown up rapidly than the growth of conventional banks.

Higgins and Schall (1975), Kim and McConnell (1977), Scott (1977), Stapleton (1982), and Shastri (1990) consider the distribution of merger gains between extant bondholders and stockholders. They argue that while total firm value may increase with a merger due to lower risk, bondholders may gain at the expense of shareholders. Similar to Lewellen's work, these papers do not have an explicit model of optimal capital structure before and after merger.5 Nonetheless, our results support many of their conclusions. Morrelec and Zhdanov 
Merger and Industrial Acceleration...

Kindy Miftah, Hendro Wibowo

(2005) presents a dynamic model of takeovers based on stock market valuations of merging firms.

In determining the alternatives of the merger, the study is based on 2 aspects: First, internal Aspect which includes: the probability (possibility) merger will be held as determined by position and interest of shareholders and interest of Sharia banks which are to be merged. Second, external aspects for industry namely impact to industry of the increase in the competitive aspect (through grater assets) and the chance of a successful merger so sharia bank from the merger may have the best value added.

The purpose of establishing the criteria's alternative of the merger is to ensure that the study could be useful in a concrete terms for discourse in sharia banking industry. The position of shareholders means similarity or closeness relation between shareholders which could be caused by group similarity, while interest of shareholder are the financial goal, regulation compliance or similar mission is related to ownership/bank supervision. On the other hand, bank interest that will be merged including the necessity to gain capital, the necessity to strengthen infrastructure or necessity is to come out from performance problems.

Beside jointly owned by government as majority, government banks (Bank $B U M N$ ) tends to have the same mission in managing bank that is to contribute into government finance and also to support the development. Therefore, from perspective of shareholder, sharia banks subsidiary of government bank (BUMN) has greater opportunity to merge compared to private sharia bank with different shareholders.

Table 3. illustrates position and interest of shareholder and sharia banks to be merged by limiting on the 10 larger sharia from the asset side. Limitation on assets tends to be line with the study which one of them is to find impact on effort optimalization in market share in sharia bank. Referring to Table 3, not all sharia banks have the possibility to be merged. Primary factor that influence the possibility is the tendency from shareholders to merge sharia bank by its subsidiary. Some banks do not have any tendency to merge because they tend to choose strategy spin-off and in short term or medium term focus on preparation and process spin-off. Dubai Islamic Bank (DIB) and Sharia Business Unit Bank Danamon and Sharia Business Unit Bank Maybank 
Indonesia influence other banks because they already have strategy investor such as

Panin Bank Sharia, which was acquired, by choosing to strengthen business model.

Table 3. The Description of Sharia Bank in term of Position

Shareholder and Interest related to the Merger

\begin{tabular}{|c|c|c|c|c|c|c|c|}
\hline \multirow[b]{2}{*}{ No } & \multirow[b]{2}{*}{$\begin{array}{l}\text { Sharia } \\
\text { Bank }\end{array}$} & \multirow[b]{2}{*}{$\begin{array}{l}\text { Asset* } \\
\text { (IDR } \\
\text { T) }\end{array}$} & \multicolumn{2}{|c|}{ Position of Shareholder } & \multicolumn{3}{|c|}{ Interest of Sharia Bank } \\
\hline & & & $\begin{array}{l}\text { A Majority } \\
\text { Shareholder }\end{array}$ & $\begin{array}{l}\text { Tendency to } \\
\text { merger subsidiary }\end{array}$ & $\begin{array}{l}\text { Need of } \\
\text { Capital }\end{array}$ & $\begin{array}{c}\text { Need of } \\
\text { Infrastructure }\end{array}$ & $\begin{array}{c}\text { Need of } \\
\text { Improvement } \\
\text { Performance }\end{array}$ \\
\hline $\mathrm{I}$ & $\begin{array}{l}\text { Bank } \\
\text { Sharia } \\
\text { Mandiri }\end{array}$ & 70,3 & $\begin{array}{l}\text { Bank Mandiri } \\
\text { (BUMN) }\end{array}$ & $\begin{array}{c}\text { Yes } \\
\text { (The Goverment } \\
\text { mission) }\end{array}$ & Yes & No & Yes \\
\hline 2 & $\begin{array}{l}\text { Bank } \\
\text { Muamalat }\end{array}$ & 57,2 & IDB** & $\begin{array}{c}\text { Yes } \\
\text { (The Divesment } \\
\text { need) }\end{array}$ & Yes & No & Yes \\
\hline 3 & BNI Sharia & 23,0 & $\begin{array}{l}\text { Bank BNI } \\
(\mathrm{BUMN})\end{array}$ & $\begin{array}{c}\text { Yes } \\
\text { (The Government } \\
\text { Mission\& Enlarge Size } \\
\text { Business) }\end{array}$ & Yes & Yes & No \\
\hline 4 & BRI Sharia & 24,2 & $\begin{array}{l}\text { Bank BRI } \\
(B \cup M N)\end{array}$ & $\begin{array}{c}\text { Yes } \\
\text { (The Government } \\
\text { Mission\& Enlarge Size } \\
\text { Business) }\end{array}$ & Yes & Yes & Yes \\
\hline 5 & $\begin{array}{l}\text { Permata } \\
\text { Sharia }\end{array}$ & 15,2 & $\begin{array}{l}\text { Standard } \\
\text { Chartered }\end{array}$ & $\begin{array}{c}\text { No } \\
\text { (Focus on } \\
\text { spin-off) }\end{array}$ & No & No & No \\
\hline 6 & $\begin{array}{l}\text { BTN } \\
\text { Sharia }\end{array}$ & 13,2 & $\begin{array}{l}\text { Bank BTN } \\
\text { (BUMN) }\end{array}$ & $\begin{array}{c}\text { Yes } \\
\text { (The Goverment } \\
\text { mission) }\end{array}$ & Yes & Yes & No \\
\hline 7 & $\begin{array}{l}\text { CIMB } \\
\text { Niaga } \\
\text { Sharia }\end{array}$ & 9,1 & CIMB Grup & $\begin{array}{c}\text { No } \\
\text { (Focus on } \\
\text { spin-off) }\end{array}$ & No & No & Yes \\
\hline 8 & $\begin{array}{l}\text { Panin } \\
\text { Sharia }\end{array}$ & 7,1 & Panin Grup & $\begin{array}{l}\text { No } \\
\text { (There is already } \\
\text { strategic investor) }\end{array}$ & No & Yes & No \\
\hline 9 & $\begin{array}{l}\text { Danamon } \\
\text { Sharia }\end{array}$ & 3,6 & $\begin{array}{c}\text { Bank } \\
\text { Danamon }\end{array}$ & $\begin{array}{l}\text { No } \\
\text { (Focus to strengthen } \\
\text { business model) }\end{array}$ & No & No & Yes \\
\hline 10 & $\begin{array}{l}\text { Bank } \\
\text { Maybank } \\
\text { Indonesia } \\
\text { Sharia }\end{array}$ & 15,9 & $\begin{array}{c}\text { Bank } \\
\text { Maybank } \\
\text { Indonesia }\end{array}$ & $\begin{array}{l}\text { No } \\
\text { (Focus to strengthen } \\
\text { business model) }\end{array}$ & No & No & No \\
\hline
\end{tabular}

*Up to December 3I, 2015 **The biggest shareholder but not majority.

Source: Annual report each Banks and various related news

On the other hand, sharia banks that are owned by shareholders that do not have any tendency doing merger also generally do not have any necessity for doing merger capital requirement, infrastructure requirement and the need to improve their performance. Thus, they are only sharia banks that have the possibility to 
Merger and Industrial Acceleration...

Kindy Miftah, Hendro Wibowo

carry out merger i.e. Bank Syariah Mandiri (BSM), Bank Muamalat (BMI), BNI Syariah, BRI Syariah and BTN Syariah.

As discussed before, selecting the position of the shareholder and interest from sharia banks subsidiary side does the merger's alternative determination. In addition, to simplify analysis, the alternatives will be discussed and analyzed in study which only 3 alternatives most likely and optimal to be decided or executed. With such limitation, then the result of analysis and discussion are made expected to be more focus and weighty.

The first criteria to determine the merger's alternative is based on internal aspect which is the position of share holder. Judging from the type of shareholder, BSM has the ultimate shareholder that is similar with three others banks sharia in this regard BNI Sharia, BRI Sharia and BTN Sharia, namely the government. While the largest shareholder of Bank Muamalat namely Islamic Development Bank (IDB) has state its intention to divest Bank Muamalat, but it hasn't managed until today.

Tabel 4. Mapping The position of Shareholder and Sharia Banks Interest

\begin{tabular}{|c|c|c|c|c|}
\hline No & Sharia Bank & $\begin{array}{l}\text { Tendency } \\
\text { The } \\
\text { Position } \\
\text { Share } \\
\text { holder* } \\
\text { for merger }\end{array}$ & $\begin{array}{c}\text { The Interest } \\
\text { Sharia Bank } \\
\text { to take } \\
\text { Benefit from } \\
\text { Merger }\end{array}$ & Explanation \\
\hline I & $\begin{array}{l}\text { Bank of Sharia } \\
\text { Mandiri (BSM) }\end{array}$ & Low & Medium & $\begin{array}{l}\text { BSM has become relatively big with relative } \\
\text { complete infrastructure so shareholder tend } \\
\text { to maintain }\end{array}$ \\
\hline 2 & Bank Muamalat & High & High & $\begin{array}{l}\text { Desire for divestation by shareholder is very } \\
\text { strong meanwhile need of capital also urgent } \\
\text { Shareholder is willing to merge as long as take }\end{array}$ \\
\hline 3 & BNI Sharia & Medium & High & $\begin{array}{l}\text { advantage from finance side and can enlarge } \\
\text { sharia bank }\end{array}$ \\
\hline 4 & BRI Sharia & Medium & High & $\begin{array}{l}\text { Shareholder is willing as long as can increase } \\
\text { contributin by incorporated and still as } \\
\text { majority }\end{array}$ \\
\hline 5 & BTN Sharia & Medium & High & $\begin{array}{l}\text { BTN Syariah is still subsidiary (UUS) and yet } \\
\text { having good infrastructure, so merger option } \\
\text { will be considered as a win-win solution. }\end{array}$ \\
\hline
\end{tabular}

*Main Bank who will be majority shareholder/Most

In the second criteria, the interest of sharia bank that will be merger has been taken into consideration. In this case, all sharia banks have the need to relate to capital especially in medium and long term, in which CAR sharia banks 
will be quickly undermined if there is no additional capital. In addition, interest to have a complete infrastructure will be a consideration for BNI Sharia, BRI Sharia and BTN Sharia. Infrastructure in this matter is related to the number and distribution outlet, reliable core banking system and qualified infrastructure ebanking (ATM, mobile/internet banking, etc). And the third is the need to accelerate performance improvement desired by BSM, Bank Muamalat and BRI Sharia. Table 4 Compile mapping the position of shareholder and interest of sharia bank to facilitate in setting alternative.

The next consideration is related to the external aspect from merger combination on sharia banks where making combination also to considerate internal aspect (position shareholder and condition sharia bank). By considering internal aspect, there are some of combinations that are not feasible consist: First, BSM merger with Bank Muamalat. BSM is relatively not a resiring an organic growth from Bank Muamalat and infrastructure. Possibility that merger in BSM is with fellow sharia banks subsidiary government bank (Bank BUMN) because of the encouragment by government. Second, BSM merger with partial sharia banks subsidiary of government bank (Bank BUMN). BSM has no incentive for merger if only with partial sharia bank subsidiary of government bank (Bank BUMN) because basically BSM doesn't require asset growth in organic way, but more to implement the government's intention to have one large government sharia bank. Third, Bank Muamalat merger with more than one sharia bank. Bank Muamalat focuses on capital requirement, not in asset and infrastructure, so it can avoid high complexity in the merger process. Fourth, Bank Muamalat merger with BTN Sharia. BTN Sharia doesn't have the status as a commercial bank and yet doesn't have the infrastructure that provides value added for Bank Muamalat. In addition, BTN is as shareholder that will be considered not having sufficient fund to meet injection in the expectation of capital Bank Muamalat.

Based on the consideration above, the analysis external aspects are prepared with any alternative possibility merger, as follows: 
Table 5. Combination Possibility Alternative Merger

\begin{tabular}{|c|c|c|c|c|c|}
\hline No & \multicolumn{2}{|c|}{ Bank Combination } & $\begin{array}{c}\text { Assets } \\
\text { Combination* } \\
\text { (IDR trillion) }\end{array}$ & $\begin{array}{c}\text { Impact of } \\
\text { Assets }\end{array}$ & $\begin{array}{c}\text { Probability } \\
\text { of } \\
\text { Success** }\end{array}$ \\
\hline 1 & $\begin{array}{l}\text { BSM } \\
\text { BNI Sharia }\end{array}$ & $\begin{array}{l}\text { BRI Sharia } \\
\text { BTN } \\
\text { Sharia }\end{array}$ & 187,9 & $\begin{array}{l}\text { Highly } \\
\text { Optimized }\end{array}$ & Low \\
\hline 2 & $\begin{array}{l}\text { BNI Sharia } \\
\text { BRI Sharia }\end{array}$ & $\begin{array}{l}\text { BTN } \\
\text { Sharia }\end{array}$ & 60,4 & $\begin{array}{l}\text { Highly } \\
\text { Optimized }\end{array}$ & Medium \\
\hline 3 & BNI Sharia & BRI Sharia & 47,2 & Optimized & Medium \\
\hline 4 & BNI Sharia & $\begin{array}{l}\text { BTN } \\
\text { Sharia }\end{array}$ & 36,2 & $\begin{array}{l}\text { Lack of } \\
\text { Optimized }\end{array}$ & High \\
\hline 5 & BRI Sharia & $\begin{array}{l}\text { BTN } \\
\text { Sharia }\end{array}$ & 37,4 & $\begin{array}{l}\text { Lack of } \\
\text { Optimized }\end{array}$ & High \\
\hline 6 & Bank Muamalat & BNI Sharia & 80,2 & Optimized & Medium \\
\hline 7 & Bank Muamalat & BRI Sharia & 81,4 & Optimized & Medium \\
\hline
\end{tabular}

From the 7 combinations merger, according to the research plan, there are only 3 alternative mergers that are made as the object of study, that only alternative which has impact assets is much optimized or have high probability will be taken. Thus, three alternatives as follow: First, alternative I: Four sharia bank subsidiary government bank (Bank BUMN). Second, alternative 2: BNI Sharia with BTN Sharia. Third, alternative 3: BRI Sharia with BTN Sharia.

Table 6. Result of Valuation Individual Bank

\begin{tabular}{clccl}
\hline No & \multicolumn{1}{c}{ Bank } & $\begin{array}{c}\text { Valuation } \\
\text { (IDR } \\
\text { billion) }\end{array}$ & PBV & Explanation \\
\hline I & Bank Sharia Mandiri & 6.047 & $\mathrm{I}, 08$ & Moderate Scenario \\
2 & BNI Sharia & 2.526 & $\mathrm{I}, 14$ & Moderate Scenario \\
3 & BRI Sharia & 2.015 & 0,86 & Moderate Scenario \\
4 & BTN Sharia & 1.604 & $\mathrm{I}, 03$ & Moderate Scenario \\
\hline \multicolumn{2}{c}{ Source: data processed } & &
\end{tabular}

After establishing three alternatives merger, valuation process with DCF method will be conducted both each banks is to be merged and also by consolidation banks in each alternative merger. Growth scenario will be used in doing calculation of the valuation consolidation alternative which the merger are using growth assumption based on historical data Mandiri Bank (for alternative I) and based on historical Bank CIMB Niaga (for alternative 2 and 3 ). 
Table 7. Result of Valuation Consolidation Bank

\begin{tabular}{clcll}
\hline No & \multicolumn{1}{c}{ Bank } & $\begin{array}{c}\text { Valuation } \\
\text { (IDR Billion) }\end{array}$ & PBV & \multicolumn{1}{c}{ Explanation } \\
\hline I & $\begin{array}{l}\text { Alternative- } \\
\text { (4 bank sharia) }\end{array}$ & 12.116 & 1,03 & $\begin{array}{l}\text { Assumption growth } \\
\text { Bank Mandiri }\end{array}$ \\
2 & $\begin{array}{l}\text { Alternative-2 } \\
\text { (BNI Sharia, BTN Sharia) }\end{array}$ & 4.567 & 1,21 & $\begin{array}{l}\text { Assumption growth } \\
\text { historical Bank } \\
3\end{array}$ \\
$\begin{array}{l}\text { Alternative-3 } \\
\text { (BRI Sharia, BTN Sharia) }\end{array}$ & 3.896 & 1,00 & CIMB Niaga \\
\hline
\end{tabular}

Source: data processed

Bank Sharia Mandiri has the largest valuation IDR 6,04 trillion influenced by the greatest equity compared to three other banks. Meanwhile, when seen from PBV, BNI Sharia has the highest PBV valuation, which is I, 14 times compare to its book value. It means that BNI Sharia has the highest selling power to investor most likely due to better performance over the last 2-3 years.

In the consolidation, alternative $I$ has the greatest valuation where it is influenced by the total number of banks. Which is combined more than the alternative 2 and alternative 3. Valuation of alternative I, amount IDR 12.1 trillion or PBV I.03 times compared to book value consolidation in four banks. Meanwhile value alternative 2 and alternative 3 amount is IDR 4.6 trillion and IDR 3.9 trillion. Based on PBV, alternative 2 has the largest PBV is I.2I time book value. Valuation PBV both individual and consolidation around 0.86 time to I.2I time shows currently valuation sharia banks which is not optimal yet compared to valuation conventional bank with big capitalisation that could reach average 2 times.

After the obtained result of valuation, the last step is to determine the optimal alternative merger based on accumulation of valuation and find business model where the focus is formed. Business model focus is being the importance things because it will determine the acceleration of process consolidation business also operational after merger. Comparison result between alternatives also business model is presented Table 8 and 9 . 
Table 8. The Comparison Accumulation Valuation between Alternatives

\begin{tabular}{clccc}
\hline No & \multicolumn{1}{c}{ Bank } & $\begin{array}{c}\text { Valuation } \\
\text { Alt-I }\end{array}$ & $\begin{array}{c}\text { Valuation } \\
\text { Alt-2 }\end{array}$ & $\begin{array}{c}\text { Valuation } \\
\text { Alt-3 }\end{array}$ \\
\hline I & BSM & & 6.047 & 6.047 \\
2 & BNI Sharia & 12.116 & 4.567 & 2.526 \\
3 & BTN Sharia & & 2.015 & 3.896 \\
4 & BRI Sharia & 12.116 & $\mathbf{1 2 . 6 2 9}$ & $\mathbf{1 2 . 4 6 8}$ \\
\hline & Accumulation & $\mathbf{1 2 . 0 4}$
\end{tabular}

Based on the comparison valuation accumulation between the alternatives above, alternative-2 has a higher valuation accumulation amount which is IDR I2,6 trillion. Furthermore, based on business model, which formed, alternative-2 also produces bank that focuses on consumer business with composition of $67 \%$. Therefore, based on valuation and also supported by the best formed business model, the merger between BNI Sharia and BTN Sharia will be the best alternative merger because it delivers the most optimal and also business model that focuses on the after merger.

Table 9. Comparison Business Model Formed

\begin{tabular}{llllll}
\hline No & \multicolumn{1}{c}{ Bank } & \multicolumn{1}{c}{ Business Strong* } & \multicolumn{1}{c}{ Alt-I } & \multicolumn{1}{c}{ Alt-2 } & \multicolumn{1}{c}{ Alt-3 } \\
\hline I & BSM & Commercial** (69\%) & - Corp I7\% & - Comm, & - Comm, \\
2 & BNI Sharia & Consumer (56\%) & - Comm, SME & SME \& & SME \& \\
3 & BTN Sharia & Consumer (85\%) & \& Micro 43\% & Micro 33\% & Micro 53\% \\
4 & BRI Sharia & Commercial** $(79 \%)$ & - Cons 40\% & - Cons 67\% & - Cons 47\% \\
\hline \multicolumn{7}{c}{$\begin{array}{c}\text { Assessment of Form Model } \\
\text { Business }\end{array}$} & $\begin{array}{c}\text { Very } \\
\text { Unfocused }\end{array}$ & $\begin{array}{c}\text { Focussed on } \\
\text { Consumer }\end{array}$ & Unfocus \\
\hline
\end{tabular}

*Business segmentation data on Annual Report 2015 each banks

**Consist of segment corporate, commercial, SME and micro

In almost all industries this underlying variability among companies leads to significant differences in their performance. An effective strategy have given a firm three benefits: (I) A source of economic gain, (2) Provide a framework for resource allocation and, (3) Guiding firm's decision regarding management and organization (Walker, 2003). Wheelen \& Hunger (2008), define strategy as a comprehensive plan that states how a corporation will achieve its mission and objectives. It maximizes competitive advantages and minimizes competitive disadvantages. To understand strategy, we need to define mission, objective, goal and policy, as follow. Strategies are the means by which long-term objective will be achieved. Strategies are potential actions that require top management decisions and large amounts of firm's resources 
(David, 2007). Multiple activities may be separated financially after the merger (Leland, 2007)

In history of Indonesian banking, Bank Mandiri and Bank CIMB Niaga have become an important and valuable history merger in banking industry. It is due to two banks that appear as big players in industry ( 10 big) both before merger process and after merger. Points and important issues in merger Bank Mandiri and Bank Niaga CIMB.

Table 10. The Comparison Merger Bank Mandiri and Bank CIMB Niaga

\begin{tabular}{|c|c|c|}
\hline & Bank Mandiri & Bank CIMB Niaga \\
\hline Merger Background & Bank restructuring/recovery & $\begin{array}{l}\text { Compliance with } \\
\text { regulation }\end{array}$ \\
\hline Year & 1998 & 2008 \\
\hline Economic Situation & Crisis and very unstable & $\begin{array}{l}\text { Mini crisis but relatively } \\
\text { still stable }\end{array}$ \\
\hline Merged Banks & $\begin{array}{l}\text { - Bapindo } \\
\text { - Bank Dagang Negara } \\
\text { - Bank Bumi Daya } \\
\text { - Bank Exim }\end{array}$ & $\begin{array}{l}\text { - Bank Niaga } \\
\text { - Bank Lippo }\end{array}$ \\
\hline Involved Shareholder & $\begin{array}{l}\text { Government, National Banking } \\
\text { Recovery Institution "Badan } \\
\text { Penyehatan Perbankan } \\
\text { Nasional" (BPPN) }\end{array}$ & $\begin{array}{l}\text { Khazanah Grup (main } \\
\text { CIMB), CIMB Grup, Lippo } \\
\text { Grup }\end{array}$ \\
\hline
\end{tabular}

Source: various sources

Although being conducted with very different background and situation, merger Bank Mandiri and Bank CIMB Niaga are both as an example of successful merger. Aside from related to assets growth and sustainable business, both Bank Mandiri and Bank CIMB Niaga also become a public company which share a very highly desirable investor in capital market. The number of banking solutions which provided, are also a more extensive network compared to the previous merger, and it would be a proof evidence that merger brings benefit to financial system and for the society itself.

Beside the size of asset, the difference result merger after is both located to financial indicators after merger. As a result of complex merger and being in the middle of an unstable economic situation, in the first year and second, the merger of Bank Mandiri posted negative profit, while profit of Bank CIMB Niaga remains positive. Negative profit of Bank Mandiri was due to the high value of bad assets belonging to 
Merger and Industrial Acceleration...

Kindy Miftah, Hendro Wibowo

the ex-legacy of the merged four banks. Meanwhile, growth net interest income also has changed in 7 years recently after merger where Bank Mandiri growth was $8 \%$ a year, while Bank CIMB Niaga can grow II\% per year.

\section{CONCLUSION}

Based on the analysis and discussion above, we can conclude that: The first, From various possibility alternative mergers between sharia banks, there are 5 alternatives that are feasible considering the internal aspect such as tendency shareholder and condition sharia bank to be merged related to internal interest in the merger action and external aspect namely scale of assets from merger banks and probability success from merger process. Second, In general valuation sharia banks both individual and consolidation (projection after-merger) are not optimal with PBV valuation in the range of 0,86-I,2I times. Third, From the available alternatives, the merger of BNI Sharia with BTN Sharia will be an optimal alternative merger by considering valuation result and also becomes the focus of business model formed and Merger policy is preferable in strengthen capital of Sharia banks compared to segregation policy.

\section{REFERENCES}

Al Arif, M.N.R. (2015a). Impact of Spin-off Policy on The Asset Growth on Indonesian Islamic Banking Industry. Journal of Islamic Economics, Banking, and Finance. Vol. II, No. 4: 4I-52.

Al Arif, M.N.R. (20I5b). Keterkaitan Kebijakan Pemisahan Terhadap Tingkat Efisiensi Pada Industri Perbankan Syariah di Indonesia. Jurnal Keuangan dan Perbankan. Vol. 19 (2): 295-304.

David, F.R. (2007). Strategic Management: Concepts and Cases. Upper Saddle River: Pearson Education Inc.

Epstein, M.J. (2005). The Determinants and Evaluation of Merger Success. Business Horizons. Vol. 48 (I): 37-46.

Gitman, L.J. \& C.J. Zutter, Chad J. (2012), Principal of Managerial Finance, Boston: Prentice Hall. 
Hamid, A. (2015), The Impact of Spin-off Policy to the Profitability on Indonesian Islamic Banking Industry. Al-lqtishad. Journal of Islamic Economics. Volume 7 (I): II7-126.

Haribowo, Ismawati, (2017), The Indonesian Islamic Bank's Spin Off: A Study In Regional Development Banks. Al-lqtishad. Journal of Islamic Economics. Volume 9 (I): 53-68.

Hite, G.L. et.al. (1984). The Separation of Real Estate Operations By Spin-Off. Real Estate Economics. Volume 12, Issue 3: 215-416.

Higgins, R. \& L. Schall. (1975). Corporate Bankruptcy and Conglomerate Merger. Journal of Finance 30: 93-113

Johnson, G, et.al. (1994). The Market Reaction to Voluntary Corporate Spin-Offs: Revisited. Quarterly Journal of Business and Economics. Vol. 33 (4): 44-57.

Kim, E.H. \& J. McConnell. (1977). Corporate Mergers and The Co-insurance of Corporate Debt. Journal of Finance. Vol. 32: 349-365.

Leland, H.E. (2007). Financial Synergies and The Optimal Scope of the Firm : Implications for Merger, Spinoff and Stuctured Finance. The Journal of Finance. Volume LXII, No.2: 765-807

Lindholm-Dahlstrand, Å. (2000). Entrepreneurial origin and spin-off performance. Proceedings of the Paper Presented at Babson College Kauffman Foundation Entrepreneurship Research Conference, June.

Morellec, E. \& A. Zhdanov. (2005). The Dynamics of Mergers and Acquisitions. Journal of Financial Economics. Vol. 77 (3): 649-672.

Pratt, S. (2008), Valuing a Business; The Analysis and Apprisal of closely Held Companies (Fifth Edition). New York: McGraw Hill.

Scott, J. (1977). On the Theory of Corporate Mergers. Journal of Finance. Vol. 32: $1235-1250$.

Shastri, K. (1990). The Differential Effects of Mergers on Corporate Security Values. Research in Finance. Vol. 8: 179-20I.

Steiger, Florian. (2008), The Validity of Company Valuation Methods Using Discounted Cash Flow. Paper Conference. Europan Business School. 
Merger and Industrial Acceleration...

Kindy Miftah, Hendro Wibowo

Stapleton, R. (1982), Mergers, Debt Capacity, and The Valuation of Corporate Loans. in M. Keenan and L. White, eds.: Mergers and Acquisitions. Lexington: Lexington Press.

Weil, J.V.D \& D. Cole. (2008). Merger and Acquisition Integration Methodology, Petroleum Accounting and Financial Management Journal. Vol.27 (2): 88-I0I.

Walker, G. (2003). Modern Competitive Strategy. New York: The McGraw-Hill.

Wheelen, T.L. \& D.J. Hunger. (2008). Strategic Management and Business Policy. Upper Saddle River: Pearson Education Inc. 